\title{
SOSOK PEREMPUAN INDONESIA DALAM NOVEL-NOVEL INDONESIA MODERN
}

\author{
Djoko Saryono \\ Fakultas Sastra Universitas Negeri Malang \\ e-mail: saryonodjoko@yahoo.co.id
}

\begin{abstract}
This study aims to describe female Indonesian figures constructed in modern Indonesian novels. The data sources were Indonesian novels presenting female main characters. The data were analyzed by means of a cyclical interactive analysis involving hermeneutic reading and understanding, holistic classification according to the research focus, and hermeneutic reinterpretation. The findings are as follows. There are a variety of female Indonesian figures represented in several serious Indonesian novels. Female figures' physical-biological identity, ethnic identity, socio-economic identity, cultural orientation, worldview, life view, life attitude, and lifestyle are relatively varied. Basically, however, female figures from the modern upper-middle class are much more dominant and stronger than those from the traditional lower class. Therefore, serious modern Indonesian novels seem to an arena of ideological introduction and operation for the interest of Indonesian middle and upper-middle classes.
\end{abstract}

Keywords: life-world, female Indonesian figures, modern Indonesian novels

\section{PENDAHULUAN}

Sastra dapat disikapi sebagai wacana yang mengatakan, membicarakan, dan atau mebahasakan peristiwa, pengalaman, dan atau kenyataan hidup dan kehidupan tertentu (Kleden, 1997). Untuk itu, penulis sastra harus membuat atau membangun sebuah model dunia-kehidupan (life world, lebenswelt) dalam karya mereka, yaitu model dunia manusiawi dan teratur yang dihayati dan dialami oleh manusia. Menurut Kayam (1987), pada dasarnya penulis certia selalu membangun atau menciptakan model dunia-kehidupan dalam karya mereka. Untuk kepentingan itu diciptakanlah tokoh-tokoh, berbagai kemungkinan hubungan antar-tokoh, berbagai latar situasi sosial dan budaya, dan lain-lain supaya model dunia-kehidupan tersebut menjadi manifes, tampak wujudnya. Dalam model dunia-ke- hidupan itulah sastrawan atau penulis fiksi mengembangkan dan membeberkan kemungkinan-kemungkinan pola penghayatan dan pemahaman tentang peristiwa, pengalaman, dan atau kenyataan hidup dan kehidupan manusia dalam karya mereka. Tanpa model dunia-kehidupan, hal tersebut niscaya tidak dapat dibentuk dan dikembangkan serta dibeberkan oleh sastrawan - yang dampak ikutannya adalah bahwa wacana sastra tidak mungkin terbangun. Hal itu mengimplikasikan bahwa model dunia-kehidupan merupakan sebuah conditio sine qua non dalam wacana sastra.

Sebagai salah satu bentuk wacana sastra, dalam novel selalu terbangun model dunia-kehidupan tertentu. Sebagai contoh, novel Layar Terkembang (St. Takdir Alisjahbana) dan Sitti Nurbaya (Marah Rusli) serta Pada Sebuah 
Kapal (Nh. Dini) terdapat model duniakehidupan tertentu. Novel Layar Terkembang memuat dunia-kehidupan yang dihayati dan dialami oleh Maria, Tuti, dan Yusuf. Novel Sitti Nurbaya mengandung dunia-kehidupan sosok Sitti Nurbaya, Datuk Meringgih, dan Samsjul Bachri. Kemudian novel Pada Sebuah Kapal menampilkan dunia-kehidupan Sri yang seorang penari dan istri seorang diplomat asing. Tidak mengherankan, di dalam novel terdapat bermacam-macam model dunia-kehidupan. Secara sosiokultural, dalam novel dapat terbangun model dunia-kehidupan kelas bawah (orang kecil), kelas menengah (priyayi), dan kelas atas serta kombinasi antarketiganya. Secara religiokultural, dapat terbangun model dunia kehidupan - misalnya - santri dan abangan. Selanjutnya, secara gender, dapat terbangun dunia-kehidupan perempuan dan lakilaki. Pelbagai model dunia-kehidupan tersebut merupakan satu kesatuan yang selalu dihayati, dialami, diikuti, dan bahkan dijalani oleh sosok-sosok yang terdapat di dalam dunia-kehidupan tersebut.

Salah model dunia-kehidupan yang terdapat dalam novel Indonesia adalah model dunia-kehidupan perempuan. Model dunia-kehidupan perempuan dalam novel Indonesia merupakan gambaran mengenai (pelbagai) bentuk dunia-kehidupan perempuan yang secara nyata/real dihayati, dialami, diikuti, bahkan dijalani oleh perempuan di dalam geografi imajinatif. Model dunia-kehidupan perempuan dalam novel Indonesia tersebut mengandung atau memiliki lima unsur konstitutif (pembentuk), yaitu (1) sosok perempuan, (2) interaksi atau hubungan gender, (3) lingkungan fisikal/spasial/ geografis perempuan, (4) lingkungan sosial budaya perempuan, dan (5) nilai-nilai budaya yang dihayati, dialami, dan/atau diikuti oleh perempuan.
Sosok perempuan merupakan salah satu unsur konstitutif model dunia-kehidupan perempuan yang sangat strategis dan penting untuk dicermati. Dikatakan demikian karena keberadaan, kedudukan, dan peranan sosok perempaun sangat strategis dan penting dalam model dunia-kehidupan perempuan. Bahkan dapat dikatakan, tanpa sosok perempuan, model dunia-kehidupan perempuan tidak dapat terbangun dan berfungsi. Selain itu, sosok perempuan juga dapat menentukan keadaan dan kualitas keempat unsur lain model dunia-kehidupan perempuan selain sosok perempuan sepenuhnya dikendalikan atau dibelenggu oleh empat unsur konstitutif yang sudah dikemukakan di muka.

Sebagai ilustrasi, sosok perempuan Sitti Nurbaya dalam novel Sitti Nurbaya dan Yah dan Tini dalam novel Belenggu mempunyai keberadaan, kedudukan, dan peranan sangat strategis dan menentukan dalam duniakehidupan perempuan di dalam kedua novel tersebut. Di samping itu, tokoh Sitti Nurbaya, Yah, dan Tini menentukan keadaan dan kualitas unsur konstitutif dunia-kehidupan perempuan lainnya. Oleh karena itu, sosok perempuan dalam dunia-kehidupan perempuan yang tampil di dalam novel, menarik dicermati dan diketahui secara mendalam dan mendetail. Untuk itu, dapat dilakukan suatu penelitian tentang sosok perempuan dalam dunia-kehidupan perempuan yang tampil dalam novel Indonesia.

Berdasarkan argumentasi tersebut penelitian bertajuk Sosok Perempuan Indonesia dalam Novel Indonesia ini dilaksanakan. Masalah yang dikaji di dalam penelitian ini adalah: (1) identitas fisikal-biologis, (2) identitas etnis, (3) identitas sosial ekonomis, (4) orientasi budaya, (5) pandangan dunia, (6) pandangan hidup, (7) sikap hidup, dan (8) 
gaya hidup tokoh-tokoh perempuan di dalam novel-novel Indonesia. Melalui kajian tersebut diharapkan dapat diketahui secara komprehensif profil atau sosok perempuan Indonesia yang tampil di dalam novel Indonesia.

\section{METODE}

Sumber data penelitian ini adalah novel-novel Indonesia sejak masa awal pertumbuhannya sampai dengan masa kontemporer sekarang yang menampilkan tokoh utama perempuan. Penentuan sumber data ini dilakukan dengan cara penyampelan internal (internal sampling), yaitu cara penentuan sampel yang didasarkan atas terwakilinya konstruksi sosok perempuan yang terdapat dalam novel, bukan jumlah novel. Dengan cara demikian, diharapkan sumber data dapat memberikan gambaran tentang sosok perempuan yang relatif utuh dan lengkap.

Sesuai dengan masalahnya, data penelitian ini terpusat atau terbatas pada tokoh utama dan tokoh bawahan perempuan dalam novel meskipun prioritas analisis diarahkan pada tokoh utama perempuan. Data penelitian itu meliputi data identitas fisikal-biologis dan etnis, identitas sosial ekonomis, orientasi budaya, pandangan dunia, pandangan hidup, sikap hidup, dan gaya hidup tokoh-tokoh perempuan di dalam wacana novel serius serius Indonesia. Data-data tersebut dikumpulkan dengan menggunakan teknik studi dokumentasi yang dibantu instrumen berupa kisi-kisi identifikasi dan klasifikasi data.

Selanjutnya, korpus data penelitian tersebut dianalisis dengan menggunakan analisis interaktif yang siklis (berputar). Langkah analisis dilakukan dengan langkah-langkah: (1) membaca untuk menghayati dan memahami secara hermeneutis sumber data dan korpus data, (2) mengidentifikasi dan mengklasifikasi seluruh data ber- dasarkan masalah, bukan berdasarkan masing-masing novel, (3) menafsirkan kembali secara hermeneutis seluruh data yang sudah diidentifikasi dan diklasifikasi, dan (4) mengulang kembali langkah-langkah tersebut apabila hasil analisis dipandang kurang memadai dan mantap.

\section{HASIL DAN PEMBAHASAN}

Yang dimaksud sosok perempuan dalam model dunia-kehidupan perempuan yang terepresentasi di dalam novel adalah gambaran wujud atau profil tokoh-tokoh perempuan yang berada, mengada, dan hidup di dalam suatu dunia-kehidupan perempuan tertentu yang terdapat dalam novel Indonesia. Dalam penelitian ini tokoh perempuan itu meliputi tokoh utama dan tokoh bawahan meskipun prioritas analisis hanya pada tokoh utama. Sosok perempuan yang relatif utuh dan lengkap meliputi identitas fisikal-biologis dan etnis, identitas sosial ekonomis, orientasi budaya, pandangan dunia, pandangan hidup, sikap hidup, dan gaya hidup tokoh-tokoh perempuan di dalam wacana novel serius Indonesia. Dengan kata lain, unsurunsur tersebut membentuk setiap sosok perempuan.

\section{Identitas Fisikal-Biologis Perempuan}

Indentitas fisikal-biologis perempuan merupakan salah satu anasir sosok perempuan yang paling cepat dan mudah dilihat dan diketahui oleh orang lain. Dikatakan demikian karena identitas fisikal-biologis kasat mata, dapat dilihat atau diindera secara langsung tanpa membutuhkan banyak perangkat tafsiran. Yang dimaksud identitas fisikal-biologis yang tidak banyak butuh tafsiran ini bisa berupa umur, warna kulit, warna rambut, pakaian, aksesoris tubuh, dan cara berjalan.

Identitas fisikal-biologis perempuan seperti ini banyak terepresentasi 
dalam wacana-wacana novel Indonesia yang dijadikan sumber data. Dengan kata lain, novel Indonesia banyak menginformasikan sekaligus merepresentasikan identitas fisikal biologis sosok perempuan baik melalui deskripsi maupun cakapan-cakapan tokoh dan lakuan-lakuan tokoh perempuan; baik secara mendetil maupun umum-selintas. Sebagai contoh, dapat diperhatikan deskripsi Marah Rusli perihal identitas fisikal-biologis Sitti Nurbaya dalam novel Sitti Nurbaya.

Alangkah elok parasnya anak perawan ini, tatkala berdiri sedemikian! Seakan-akan dagang yang rawan, yang bercintakan sesuatu, yang tak mudah diperolehnya. Pipinya sebagai pauh dilayang, yang kemerah-merahan warnanya kena bayang baju dan payungnya, bertambah merah rupanya, kena panas matahari. Apabila ia tertawa, cekunglah kedua pipinya, menambahkan manis rupanya; istimewa pula karena pada pipi kirinya ada tahi lalat yang hitam. Pandangan matanya tenang dan lembut, sebagai janda baru bangun tidur. Hidungnya mancung, sebagai bunga melur,

bibirnya halus, sebagai delima merekah, dan di antara kedua bibir itu kelihatan giginya, rapat berjejer, sebagai dua baris gading yang putih. Dagungnya sebagai lebah bergantung, dan pada kedua belah cuping telinganya kelihatan subang perak, yang bermatakan berlian besar, yang memancarkan cahaya air embun. Di lehernya yang jenjang, tergantung pada rantai emas yang halus, sebuah dokoh hati-hati, yang bermatakan permata de- lima. Jika ia minum, seakan-akan terbayanglah air yang diminumnya di dalam kerongkongannya. Suaranya lemah-lembut, bagai bulu perindu, memberi pilu yang mendengarnya. Dadanya bidang, pinggangnya ramping. Lengannya dilingkari gelang ular-ular, yang bermatakan beberapa butir berlian yang bernyala-nyala sinarnya. Pada jari manis tangan kirinya yang halus itu, kelihatan sebentuk cincin mutiara, yang besar matanya. Kakinya baik tokohnya maupun jalannya lemah gemula. (SN:9--10)

Dalam kutipan novel Sitti Nurbaya di atas, identitas fisikal-biologis Sitti Nurbaya dideskripsikan oleh pengarang secara mendetil dan berkecil-kecil. Sebaliknya, dalam novel serius Burungburung Manyar, identitas fisikal-biologis Larasati dideskripsikan oleh pengarang secara umum-selintas di samping ditunjukkan melalui lakuan Larasati dan cakapan Mbok Naya dan Mbok Ranu, kedua pengasuhnya. Ini dapat diperhatikan kutipan dari Burung-burung Manyar berikut.

Wijen? Aduh cantiknya Den Rara Larasati! Wijen? dan Mbok Naya menyeka manja gadis cilik yang baru saja merebahkan diri duduk di atas amben dan yang tersenyum manis merayunya. Mbok Naya tertawa geli. "Wijen untuk apa Den Rara?"

"Saya bukan Den Rara. Saya At-tik. Sudah."

Mbok Naya lebih ketawa lagi, dan temannya Mbok Ranu di sebelahnya, juga ikut tertawa, samasama terlonjak hati melihat noni Jawa dari Betawi itu begitu lucu, lesung di pipi, berbahasa Jawa kurang sempurna untuk ukuran 
lingkungan pangeran karaton, Surakarta lagi. (BB:10)

Dalam novel Indonesia yang dijadikan sumber data, terepresentasi bermacam-macam identitas fisikal-biologis perempuan. Secara umum, identitas fisikal-biologis perempuan yang direpresentasikan meliputi kategori (keadaan) umur, postur, keadaan, dan aksesoris diri (tubuh dan wajah). Kategori (keadaan) umur yang dimaksud di sini bisa berupa deskripsi, cakapan, dan/atau penyebutan dengan istilah kunci, misalnya, umurnya 15 tahun (an), umurnya 25 tahun (an); umurnya masih muda, usianya setengah baya; (k)anak-(k)anak, anak (orang) muda, (orang) tua (bangka); dan perempuan muda, perempuan tua. Sementara itu, postur, keadaan, dan aksesoris diri (tubuh dan wajah) dapat berupa deskripsi, cakapan, dan penyebutan dengan istilah kunci, misalnya, elok parasnya, gadis, perawam, pipinya sebagai pauh dilayang, perempuan muda bertubuh pahatan emas, cantiknya wajahnya, dan sebuah liontin melilit lehernya. Sebagai contoh, di samping dua kutipan dari Sitti Nurbaya dan Burung-burung Manyar di atas, perhatikan kutipan pendek dari Kotbah di Atas Bukit berikut.

Sebenarnya, Barman tua suka mempunyai kekasih semacam Popi. Ia akan memanggil-manggil: "Popi, sayang!" Lalu perempuan muda bertubuh pahatan emas itu akan datang, menciumnya dan berkata: "Engkau dingin pap, kasihan". (KAB:1).

Perhatikan pula kutipan dari novel serius Tirai Menurun berikut.

... Sumirat tumbuh bagikan tanaman subur. Wajahnya menyinarkan kecerahan yang pasti. Kulitnya bersih, tidak seperti ga- dis-gadis remaja di lingkungannya. (TM:217)

Untuk kepentingan cerita, deskripsi, cakapan, dan lakuan yang menggambarkan identitas fisikal-biologis perempuan tidak dikemukakan dalam satu bagian tertentu, tetapi tersebar dalam berbagai bagian novel. Dengan kata lain, identitas fisikal-biologis tidak dikemukakan sekaligus secara lengkap, tetapi tersebar dan bertahap secara berangsur-angsur. Hal ini terlihat dalam hampir semua novel yang diteliti walaupun harus disadari ada keunikan pada masing-masing (periode). Dapat dikatakan, tidak ada satu pun novel yang menggambarkan identitas fisikal-biologis perempuan secara serempak dan sekaligus.

Sebagian besar novel yang diteliti merepresentasikan identitas fisikal-biologis perempuan muda dengan istilah kunci, misalnya, perempuan muda/gadis/ perawan mudalanak muda. Pendeknya, perempuan mudalah yang secara dominan direpresentasikan oleh novel Indonesia. Novel Sitti Nurbaya, Layar Terkembang, Andang Teruna, Burung-burung Manyar, Raumanen, Kotbah di Atas Bukit, Pada Sebuah Kapal, Ronggeng Dukuh Paruk, Tirai Menurun, dan Saman, sebagai contoh, menampilkan perempuan-perempuan muda. Selain itu, kebanyakan novel Indonesia merepresentasikan perempuan muda berparas rupawan, cantik, dan bersih. Ini juga tampak dalam novel yang sudah disebut di atas: tokoh Sitti Nurbaya dalam Sitti Nurbaya, tokoh Tuti dan Maria dalam Layar Terkembang, tokoh Larasati dalam Burungburung Manyar, tokoh Raumanen dalam Raumanen, tokoh Popy dalam Kotbah di Atas Bukit, tokoh Sri dalam Pada Sebuah Kapal, tokoh Srintil dalam Ronggeng Dukuh Paruk, tokoh Kedasih dan Sumirat dalam Tirai Menurun, dan tokoh Yasmin dan Shakuntala dalam Saman adalah 
perempuan-perempuan berparas rupawan, cantik, dan bersih dalam lingkaran mereka masing-masing atau lingkungan mereka masing-masing.

Perempuan muda jelek atau tidak terurus, kotor, dan kumuh sedikit (sekali) direpresentasikan oleh wacanawacana novel Indonesia. Di antara yang sedikit itu adalah wacana novel Merahnya Merah, Ibu Kita Raminten, Pengakuan Pariyem, dan Bekisar Merah: tokoh Maria dan Fifi dalam Merahnya Merah, tokoh Raminten dalam Ibu Kita Raminten, dan tokoh Pariyem dalam Pengakuan Pariyem serta tokoh Lasi dalam Bekisar Merah digambarkan memiliki identitas fisikal tidak terurus, kotor, dan kumuh karena mereka merupakan perempuan muda kelas bawah dan perempuan jalanan (gelandangan).

Identitas fisikal-biologis perempuan dewasa atau tua dengan istilah kunci, misalnya, perempuan tualtua bangka/isteri/wanita tengah baya tidak banyak direpresentasikan dalam wacana novel Indonesia. Di antaranya novel Ibu Kita Raminten, Wanita itu adalah Ibu, Bukan Rumahku, Bumi Manusia, Burung-burung Manyar, Burung-burung Rantau, Ny. Talis, dan Aku Supiah Isteri Hardian. Perempuan dewasa atau tua yang direpresentasikan tersebut sebagian besar adalah perempuan dewasa berparas cantik, berdandan rapi, terawat, dan bersih atau tidak kumuh-kotor. Tokoh Nuning dalam Wanita Itu adalah Ibu, Nyai Ontosoroh dalam Bumi Manusia, Marice Brajabasuki dan Ibu Antana dalam Burung-burung Manyar, Yuniati dalam Burung-burung Rantau, Ny. Talis dalam Ny Talis, dan Supiah dalam Aku Supiah Isteri Hardian merupakan perempuan tua yang berdandan rapi, terawat, bersih, bahkan relatif cantik.

Perempuan dewasa atau tua berparas jelek, berdandan tidak rapi dan tidak terawat, atau kumuh-kotor relatif sedikit direpresentasikan dalam novel
Indonesia. Di antaranya yang merepresentasikannya adalah novel Ibu Kita Raminten, Burung-burung Manyar, dan Tirai Menurun. Tokoh Raminten dalam Ibu Kita Raminten, tokoh Mbok Naya dan Mbok Ranu, dan tokoh Simbok dalam Tirai Menurun adalah perempuan tua, berdandan kurang rapi, bahkan kurang terawat (karena mereka memang orangorang kelas bawah. Pada umumnya mereka merupakan tokoh-tokoh kurang dalam keseluruhan cerita novel. Sebagian besar novel yang diteliti tampaknya memang menokohkan perempuan dewasa atau tua sebagai tokoh samping dan minor. Misalnya, pembantu, gelandangan, atau petani miskin di desa, sehingga novel-novel itu merepresentasikannya dengan identitas-fisikal perempuan tua atau dewasa yang jelek dan berdandan kurang rapi/terawat.

\section{Identitas Etnis Perempuan}

Di samping identitas-identitas fisikal-biologis tersebut, sosok perempuan menjadi jelas dan tegas dengan identitas etnis perempuan. Berdasarkan identitas etnisnya, dapat dikatakan bahwa dalam novel-novel yang dijadikan sumber data merepresentasikan perempuan-perempuan dari berbagai etnis di Indonesia, bahkan perempuan campuran (indo) antara etnis di Indonesia dan etnis di Barat. Perempuan-perempuan dari etnis Minangkabau, Sunda, Jawa, Bali, Dayak, Madano, dan sebagainya tersepresentasi dalam novel yang diteliti.

Tokoh Sitti Nurbaya dalam Sitti Nurbaya, Asnah dan Asri dalam Salah Pilih, Rapiah dalam Salah Asuhan, dan Halimah dalam Sengsara Membawa Nikmat adalah contoh perempuan beretnis $\mathrm{Mi}$ nangkabau. Contoh perempuan beretnis Sunda adalah Dirsina dan Nuraini dalam Asmara Jaya (Adinegoro), Kartini dalam Atheis, dan Fatimah dalam Royan Revolusi. Kemudian, Sukreni dalam Sukreni Gadis Bali, Ni Rawit Ceti dalam Ni 
Rawit Ceti Penjual Orang, dan Gusti Ayu Pandan Sari dalam Nusa Pedina merupakan contoh sosok perempuan beretnis Bali. Raumanen (Manen) dalam Raumanen adalah contoh perempuan Madano. Mariamin dalam Azab dan Sengsara merupakan perempuan Batak sebagaimana dideskripsikan Marari Siregar: "Dari pakaian Mariamin tahulah dia bahwa Mariamin orang Batak, seorang bangsanya" (ADS:159). Sementara itu, Waning dalam Upacara dan Nori dalam Api Awan Asab merupakan dua contoh sosok perempuan beretnis Dayak.

Bukan hanya perempuan etnis lokal Indonesia, dalam novel Indonesia juga terepresentasi sosok-sosok perempuan indo (etnis campuran lokal dan orang asing). Sebagai contoh, tokoh Corrie de Busse (campuran Minang dan Belanda) dalam Salah Asuhan, Annelies (campuran Jawa dan Belanda) dalam Bumi Manusia, dan Marice Brajabasuki (campuran Belanda dan Jawa) dalam Burung-burung Manyar merupakan perempuan-perempuan indo. Contoh-contoh tersebut menandakan bahwa identitas etnis tokoh-tokoh perempuan relatif beragam.

Berdasarkan analisis data diketahui bahwa etnis Minangkabau-Melayu dan Jawa terepresentasi secara dominan. Identitas etnis Minangkabau-Melayu dan Jawa dilekatkan pada tokohtokoh perempuan yang ditampilkan oleh sebagian besar novel. Tokoh perempuan beridentitas etnis Minangkabau-Melayu secara dominan terepresentasi dalam novel Indonesia terbitan Sebelum Perang Kemerdekaan. Sebaliknya, sebagian besar novel terbitan Sesudah Perang Kemerdekaan terpresentasi sosok perempuan beridentitas etnis Jawa secara dominan. Di samping itu, sekalipun tidak dominan, juga terepresentasi sosok perempuan beridentitas etnis Batak, Sunda, Bali, Madano, Bugis, Dayak. Dalam novel terbitan Sesu- dah Perang Kemerdekaan juga tampil sosok perempuan yang identitas etnisnya tidak dikemukakan secara tersurat oleh pengarang baik dalam deskripsi, cakapan, maupun lakuan. Kenyataan itu mencerminkan bahwa novel-novel terbitan Sebelum Perang Kemerdekaan sebagian besar merupakan "novel novel Sumatra" khususnya Minangkabau-Melayu, sedangkan terbitan Sesudah Perang Kemerdekaan sebagian besar merupakan "novel-novel Jawa". Sebagai catatan, novel terbitan Sesudah Perang Kemerdekaan merepresentasikan sosok perempuan dengan identitas etnis lebih bervariasi daripada novel terbitan Sebelum Perang Kemerdekaan.

\section{Identitas Sosial Ekonomis}

Identitas sosial-ekonomis makin memperjelas dan memperkuat sosok perempuan dalam novel Indonesia. Justru identitas sosial ekonomis perempuan selalu tampil lebih ajek, kuat, dan dominan daripada identitas fisikal-biologis dan etnis perempuan. Dikatakan demikian karena identitas fisikal-biologis, lebih-lebih identitas etnis, tidak selalu terepresentasi dalam novel, sedangkanidentitassosial-ekonomisperempuan justru selalu dapat ditemukan melalui deskripsi, cakapan, dan/atau lakuan walaupun tidak selalu lengkap.

Identitas sosial ekonomis perempuan yang dimaksud di sini meliputi: (a) status atau kedudukan sosial perempuan, (b) kelas/lapisan/golongan sosial perempuan, (c) tingkat pendidikan perempuan, (d) jenis pekerjaan atau profesi perempuan, dan (e) kemampuan/keadaan ekonomi [kekayaan] perempuan. Status atau kedudukan sosial seorang perempuan pada umumnya ditentukan oleh tingkat pendidikan, pekerjaan atau profesi, dan kemampuan/keadaan ekonomi perempuan di samping agama dan anasir biologis. Sementara itu, kelas/lapisan/golongan sosial perempuan pada 
umumnya ditentukan oleh status sosialnya sehingga secara tidak langsung ditentukan pula oleh tingkat pendidikan, pekerjaan atau profesi, dan kemampuan ekonomi. Secara umum kelas/lapisan/ golongan sosial perempuan ini dapat dibagi menjadi (a) golongan bawah, (b) golongan menengah, dan (c) golongan atas. Golongan bawah tentu saja status sosialnya dipandang tidak terhormat, tidak terpandang, dan rendah pendidikan serta lemah kemampuan ekonomi, bahkan juga tidak mandiri. Golongan menengah status sosialnya dipersepsi relatif terpandang, terhormat, dan baik, bahkan umumnya dipandang memiliki kemandirian kuat. Adapun golongan atas status sosialnya dipersepsi sangat terhormat, terpandang, dan sangat baik sebab pendidikannya tinggi, profesi atau pekerjaannya tidak mudah dimasuki golongan lain, dan kemampuan ekonominya lebih dari pada memadai [berlebih].

Identitas sosial ekonomis Tuti dalam novel serius Sitti Nurbaya meliputi status sosial dan golongan sosial Tuti dalam masyarakat. Tokoh Tuti termasuk perempuan golongan menengah-atas dan berstatus sosial terhormat karena pendidikannya tergolong tinggi pada masanya, pekerjaan atau profesinya terhormat atau terpandang dalam masyarakat pada masanya, keadaan dan kemampuan ekonominya cukup, dan kemandirian pribadinya sangat kuat. Relatif sama dengan Tuti, Larasati (Atik) dalam Burung-burung Manyar juga menempati golongan sosial menengah-atas atau priyayi dan berstatus sosial sebagai perempuan terhormat atau terpandang dalam masyarakat luas. Dikatakan demikian karena ia berpendidikan doktor (sangat tinggi bagi perempuan pada masanya), pakar biologi yang sangat piawai memadukan bidangnya dengan filsafat manusia, berprofesi sebagai dosen sebuah universitas terkemuka, dan berkemampuan ekonomi sangat baik di samping secara genealogis memiliki trah priyayi. Demikian juga Ni (Subandini) dalam novel serius Canting termasuk golongan menengah-atas dan berstatus sosial terhormat karena dia termasuk kaya secara ekonomis, berpendidikan tinggi (sarjana farmasi), dan berprofesi terhormat atau terpandang sebagai juragan batik di samping memang secara genealogis keturunan priyayi.

Sebaliknya, Pariyem dalam novel Pengakuan Pariyem termasuk perempuan golongan bawah dan status sosialnya kurang terpandang, sekalipun tetap terhormat secara moral-etis. Dikatakan demikian karena dia berpendidikan rendah (tidak tamat SD), berprofesi sebagai pembantu rumah tangga, secara ekonomis termasuk miskin, tidak memiliki kemandirian, dan secara moral ambivalen. Relatif sama dengan Pariyem, Raminten dalam Ibu Kita Raminten termasuk perempuan golongan bawah dan statusnya kurang terpandang karena pendidikannya rendah, profesinya pemulung, kehidupan ekonomisnya pas-pasan, dan kemandiriannya lemah. Hampir sama dengan Pariyem dan Raminten, Simbok dalam Tirai Menurun termasuk golongan bawah dan status sosialnya kurang terpandang sebab pendidikannya rendah, pekerjaannya buruh tani, dan termasuk orang miskin.

Novel- novel Layar Terkembang, Salah Asuhan, Belenggu, Jalan Tak Ada Ujung, Hati Yang Damai, Pada Sebuah Kapal, Pelabuhan Hati, Bumi Manusia, Durga Umayi, Burung-burung Rantau, Saman, dan Dari Lembah ke Coolibah, sebagai contoh novel terbitan tahun 1920-an sampai dengan terbitan 1990-an, yang merepresentasikan perempuan-perempuan golongan menengah, menengahatas, dan atas kota atau modern. Sementara itu, wacana novel serius Merahnya Merah, Telegram, Pengakuan Pariyem, Ibu Kita Raminten, Ronggeng Dukuh Paruk 
(Lintang Kemukus Dini Hari, Jantera Bianglala), dan Tirai Menurun, sebagai contoh, merupakan sebagian wacana novel serius Indonesia yang secara kuat merepresentasikan perempuan-perempuan golongan bawah perkotaan (modern) dan perdesaan (tradisional).

Berdasarkan analisis dapat disimpulkan bahwa sebagian besar novel Indonesia merepresentasikan perempuanperempuan yang pada masa masingmasing menempati golongan sosial menengah atau menengah-atas dan golongan sosial atas. Perempuan-perempuan golongan bawah atau menengah-bawah relatif sedikit direpresentasikan dalam novel Indonesia. Tampaknya, novel Indonesia secara dominan merepresentasikan gejala golongan sosial sekaligus status sosial perempuan perkotaan atau modern. Lebih jauh hal ini mengimplikasikan bahwa berdasarkan golongan sosial dan status sosial tokoh perempuan di dalamnya, novel Indonesia menampilkan perempuan perkotaan yang terpelajar, terdidik, berpenghasilan cukup, atau berkemampuan ekonomi cukup.

\section{Orientasi Budaya Perempuan}

Selain unsur identitas fisikal-biologis, etnis, dan sosial ekonomis yang sudah dikemukan di atas, unsur kultural khususnya orientasi budaya perempuan semakin mempertegas sosok-sosok perempuan dalam dunia-kehidupan perempuan yang terepresentasi dalam novel Indonesia. Tokoh-tokoh perempuan di atas makin tegas sosok keperempuanan mereka jika dilihat juga orientasi budaya mereka. Dalam hal ini orientasi budaya berkaitan dengan tinjauan arah budaya yang dianggap benar dan tepat oleh kelompok atau golongan tertentu yang selanjutnya diikuti oleh golongan itu (Sastrowardoyo, 1980). Suatu budaya dapat menjadi sumber budaya bagi sekelompok atau segolongan orang.
Sastrowardoyo mencontohkan, Chairil Anwar memiliki orientasi budaya ke budaya Barat. Maksudnya, Chairil Anwar menjadikan budaya Barat, yang notabene rasional, fungsional, material, dan modern, sebagai arah budaya yang diikutinya.

Atas dasar hal itu dapat dikatakan bahwa orientasi budaya perempuan berkaitan dengan tinjauan arah budaya yang dianggap benar dan tepat oleh perempuan, yang selanjutnya diikuti atau dianut oleh perempuan. Orientasi budaya perempuan ini dapat dibedakan menjadi orientasi: (1) budaya spiritual dan/atau budaya material, (2) budaya tradisi/tradisional dan/atau budaya modern, (3) budaya mitis, budaya ontologis, dan/atau budaya fungsional, dan (4) budaya naif, budaya semitransitif, dan/atau budaya transitif (Geertz, 1983; Kartodirdjo, dkk., 1987; Koentjaraningrat, 1984).

Dalam novel Canting ditemukan dua orientasi budaya perempuan: tokoh Bu Bei (Sestrokusumo) mengikuti orientasi budaya semi-spiritual, semi-tradisional, semi-ontologis, dan semi-transitif, sedangkan tokoh $\mathrm{Ni}$ (Subandini -- anak Bu Bei) mengikuti orientasi budaya (sepenuhnya) material, modern, fungsional, dan transitif. Dalam novel Ronggeng Dukuh Paruk, Lintang Kemukus Dini Hari, dan Jantera Bianglala, sepenuhnya berorientasi budaya spiritual, tradisional, mitis, dan naif. Adapun dalam novel Durga Umayi, Burung-burung Rantau, dan Saman, tokoh perempuannya berorientasi budaya material, modern, fungsional, dan transitif. Ini mengimplikasikan, novel Indonesia tertentu atau beberapa novel Indonesia dapat merepresentasikan hanya orientasi budaya tertentu dari tokoh-tokoh perempuan, dapat pula merepresentasikan berbagai orientasi budaya dari tokoh-tokoh perempuan. 
Perempuan-perempuan yang berorientasi budaya spiritual, tradisi/ tradisional, mitis, dan naif dalam novel Indonesia di antaranya Ken Dedes, Mas Ayu Prabu atau Sayu Wiwit, Roro Mendut, Sri Sumarah, Bawuk, Pariyem, Raminten, Bu Bei, Ibu Sinder, Poppy, Srintil, Simbok, Kedasih, Sumirat, dan Lasi. Dalam novel Arok Dedes (Pramoedya Ananta Toer), Ken Dedes digambarkan selalu taat mengikuti ritual-ritual spiritual yang sudah mapan, taat kepada tata nilai yang berlaku, tidak memiliki obsesi kepada hal-hal material atau sekular;tidak memiliki kesadaran untuk menjaga jarak dengan alam semesta. Mas Ayu Prabu dalam trilogi Gema di Ufuk Timur, Tanah Semenanjung, dan Banyuwangi digambarkan sedemikian taat kepada ajaran dan ritus Hindu yang diyakininya, kesadarannya menjaga jarak dengan alam semesta tampak tidak kuat, dan obsesi terhadap hal-hal material dan sekular tak tampak kuat meskipun ketajaman politiknya baik. Demikian juga Roro Mendut dalam trilogi Roro Mendut, Lusi Lindri, dan Genduk Duku (Mangunwijaya) digambarkan sedemikian taat kepada tradisi budayanya dan obsesi kepada hal-hal material dan sekular relatif rendah meskipun memiliki keteguhan sikap yang mengagumkan. Kemudian Sri Sumarah dalam Sri Sumarah digambarkan sedemikian taat kepada tata nilai budaya Jawa priyayi yang sangat spiritual, tidak terobsesi oleh hal-hal material dan sekular, dan alam pikirannya lebih meneladani alam semesta sekalipun dia hidup di kota dan pernah bersuami seorang guru. Relatif sama dengan Sri Sumarah, Bawuk dalam Bawuk digambarkan lebih banyak menuruti hati nurani, bahkan mungkin nalurinya; logika salah-benar tidak banyak dipakai untuk mempertimbangkan pelbagai keputusannya. Bahkan Pariyem dalam prosa liris Pengakuan Pariyem digambarkan sangat percaya kepada hal-hal mistis, tidak memiliki kesadaran akan nasibnya, jalan berpikirnya sangat sederhana, dan sangat percaya kepada perlambang-perlambang gaib. Selanjutnya, sekalipun secara genealogis sebagai priyayi yang memiliki kemampuan material cukup, Bu Bei dalam novel serius Canting dan Ibu Sinder dalam novel serius Ibu Sinder masih menekankan olah rohani, sangat percaya kepada kekuatan-kekuatan supranatural, mengutamakan pengambilan keputusan berdasarkan pertimbangan rasa, dan sangat taat kepada tata nilai budaya Jawa mereka. Srintil dalam Ronggeng Dukuh Paruk, Lintang Kemukus Dini Hari, dan Jantera Bianglala digambarkan tidak pernah mampu menyadari hidup dan nasibnya, hidupnya mengalir berdasarkan garis nasib yang sudah ditetapkan untuk dirinya, dan kesadarannya untuk menjaga jarak dengan alam semesta demikian rendah.

Perempuan-perempuan yang berorientasi budaya spiritual, mitis, naif, dan atau tradisional tersebut meliputi perempuan tua (Simbok, Sri Sumarah, $\mathrm{Bu}$ Bei, Ibu Sinder) dan perempuan muda (Srintil, Lasi, Kedasih, Sumirat). Hal ini menandakan bahwa pemelukan orientasi budaya tersebut tidak berkaitan dengan umur tokoh-tokoh perempuan;umur tidak mempengaruhi orientasi budaya seorang perempuan.

Kemudian perempuan-perempuan yang berorientasi budaya semi-material (atau semi-spiritual), semi-modern (atau semi-tradisi), ontologis, dan semitransitif di antaranya Mariamin, Sitti Nurbaya, Maria, Fatimah, Bu Antana, Yuniati, dan Supiyah. Mariamin dalam Azab dan Sengsara (Kisah Kehidupan Seorang Anak Gadis) digambarkan sudah memiliki kesadaran akan hidup dan nasibnya, mampu mengambil jarak dengan semesta, dan menjaga jarak dengan tradisi yang melingkupinya meskipun belum mampu mengatasi masalah 
struktural dan tradisi yang membelenggunya. Kemudian Sitti Nurbaya dalam SittiNurbaya (Kasih Tak Sampai) digambarkan sudah mampu berpikir logis, berpikiran cukup maju, memiliki kesadaran akan hidup dan nasibnya, dan menimbang-nimbang baik buruk suatu pilihan meskipun belum mampu melepaskan diri dari belenggu tradisi dan struktur masyarakatnya.

Demikian pula Maria dalam novel serius Layar Terkembang digambarkan lebih menuruti kata hati daripada berpikir rasional meskipun sebenarnya dia sudah mampu menyadari keberadaannya, memiliki pengetahuan modern, dan mampu melepaskan diri dari kungkungan berpikir mitis. Fatimah dalam Jalan Tak Ada Ujung mampu menghargai halhal bersifat material dan sekular (duniawi), mampu berpikir secara rasional, dan menyadari keberadaannya di dunia meskipun masih terjebak ke dalam lubang-lubang persoalan yang mungkin tak disadarinya, misalnya berselingkuh dengan Hazil, sahabat suaminya Guru Isa. Bu Antana dalam Burung-burung Manyar digambarkan memiliki kemampuan bertindak kritis terhadap tradisi priyayi Jawanya, menghormati hal-hal material dan sekular, berpikiran relatif maju berkat pendidikannya, dan memiliki kemampuan berdebat dengan anaknya Larasati meskipun dia masih percaya kepada tradisi Jawanya dan sering menggunakan kata hati. Selanjutnya, Yuniati dalam Burung-burung Rantau digambarkan sebagai perempuan kaya raya berkat jabatan suaminya (tanda penghormatan kepada hal-hal material dan sekular), berpendidikan relatif baik (sehingga bisa kritis meskipun tetap bijak), dan memiliki kemampuan berdebat dengan anak-anaknya yang rata-rata berpendidikan tinggi. Adapun Supiyah dalam Aku Supiyah Isteri Hardian dan Tersenyum pun Bukan Untukku Lagi (Titis Basino) digambarkan sudah memiliki kesadaran akan hidup dan nasibnya, mampu mengambil keputusan secara individual (sekalipun belum tentu benar dan tepat), dan berada dalam lingkungan modern yang menuntutnya berpikir rasional. Tokoh-tokoh perempuan tersebut meliputi perempuan muda dan perempuan tua. Sebab itu, dapat dikatakan, orientasi budaya semi-material, semi-modern, ontologis, dan semitransitif dapat diikuti oleh perempuan muda dan tua.

Sementara itu, perempuan-perempuan yang secara kuat berorientasi budaya material (dan sekular), modern, fungsional, dan transitif di antaranya Tuti, Yah (Rochayah), Sri, Atik (Larasati), Olenka, Nyai Ontosoroh, Iin Nusamusbida, Anggraeni, Marinetti, Shakuntala, Yasmin, dan Laila. Tokoh-tokoh perempuan tersebut dapat dikatakan sepenuhnya mengikuti budaya modern, fungsional, dan transitif secara kuat dan total. Tuti dalam novel serius Layar Terkembang digambarkan berpikiran sangat maju pada zamanya, bersikap sekaligus berpikiran kritis terhadap tradisi dan kondisi masyarakatnya khususnya kaum perempuan, mampu berpikir rasional dan logis jauh melebihi perempuan sezamannya, dan gigih memperjuangkan kebebasan dan kemerdekaan kaum perempuan. Kemudian Sri dalam novel serius Pada Sebuah Kapal digambarkan memiliki kesadaran kuat akan hidup dan nasibnya, mampu berpikir rasional dan logis (sekalipun tak selalu baik dampaknya), dan mampu melontarkan kritik-kritik atas ketidakadilan yang ditimpakan kepadanya. Atik (Larasati) dalam Burung-burung Manyar digambarkan berpikir sangat rasional (sebab berpendidikan doktor), mampu melakukan sofistikasi filosofis atas berbagai fenomena alam, mampu berdebat dan melontarkan kritik kepada seseorang, menghargai profesi-profesi modern yang amat material, dan menjalani kehi- 
dupan dalam lingkungan modern. Nyai Ontosoroh dalam novel serius Bumi Manusia digambarkan menghargai materi, mampu berpikir rasional, mampu mengevaluasi dan mengkritik pelbagai ketidakadilan yang dilakukan oleh kolonial Belanda, dan gigih memperjuangkan atau menolak ketidakadilan; dia tidak pernah pasrah atas nasib dan hidupnya meskipun perjuangannya untuk memperbaiki nasib dan hidup belum tercapai akibat masalah-masalah struktural. Iin Nusamusbida dalam Durga Umayi juga digambarkan sangat menghargai materi (dia seorang konglomerat kelas kakap), mampu berpikir sangat rasional, gigih mengubah nasib dan hidupnya ke arah lebih baik, dan mampu menentukan pilihan-pilihan hidupnya secara mandiri dan individual.

Selanjutnya, Anggreni dan (Mari)netti dalam novel serius Burungburung Rantau digambarkan sebagai perempuan yang sudah merantau ke berbagai budaya modern, rasional, dan fungsional yang notabene budaya Barat: mereka adalah perempuan kosmopolitan dan mondial yang mampu melakukan perhitungan-perhitungan atas hidup dan nasib dirinya dan masyarakatnya. Adapun Shakuntala, Yasmin, dan Laila dalam novel serius Saman digambarkan sebagai perempuan yang kritis, mampu berdebat dan melakukan kritik, memiliki kemandirian dan kebebasan individual sangat tinggi, dan hidup dalam dunia internet dan digital yang pascamodern. Contoh-contoh tersebut menegaskan betapa orientasi budaya modern (bahkan sangat modern), material, fungsional, dan transitif juga banyak diikuti oleh para perempuan.

Berdasarkan analisis data, diketahui bahwa novel Indonesia lebih banyak merepresentasikan perempuan yang berorientasi budaya material, modern, fungsional, dan transitif daripada perempuan yang berorientasi budaya semi-material, semi-modern, ontologis, dan semitransitif atau perempuan yang berorientasi budaya spiritual, tradisi/ tradisional, mitis, dan naif. Representasi perempuan yang berorientasi budaya spiritual, tradisi, mitis, dan naif malah jauh lebih sedikit dibandingan dengan representasi perempuan yang orientasi budaya semi-material, semi-modern, ontologis, dan semi-transitif. Bahkan dapat disimpulkan bahwa sebagian besar novel Indonesia yang diteliti merepresentasikan perempuan yang berorientasi budaya modern, material, fungsional, dan transitif.

\section{Pandangan Dunia Perempuan}

Orientasi budaya yang dikemukakan di atas akan menentukan pandangan dunia (world view, weltanschauung) dan pandangan hidup (world life, lebenschauung) tokoh-tokoh perempuan. Sebagaimana dikemukakan Kleden (1987), pandangan dunia dan pandangan hidup manusia pertama-tama bersumberkan budaya. Dengan kata lain, dalam novel Indonesia, pandangan dunia dan pandangan hidup perempuan ditentukan oleh orientasi budaya mereka. Pandangan dunia perempuan akan memungkinkan seorang perempuan mampu menangkap dunianya ke dalam persepsinya (ontologi), dan menangkapnya sebagai sesuatu yang bermakna dan beraturan, bukan sebagai sesuatu yang kacau (kosmologi). Ontologi dari pandangan dunia ini akan membuat budaya menjadi realitas, sedangkan kosmologi dari pandangan dunia akan membuat budaya menjadi sistem realitas dan sistem makna.

Jika pandangan dunia perempuan itu diterjemahkan atau dimanifestasikan menjadi perangkat aturan bagi perempuan atau tata tingkah laku bagi perempuan, maka akan didapatkan pandangan hidup perempuan. Pandangan hidup di sini menjadi manifestasi 
dan operasionalisasi pandangan dunia. Sebagaimana dikemukakan oleh Mulder (1986), di sini pandangan hidup menjadi sebuah pengaturan mental dari pengalaman. Pandangan hidup ini tidak hanya memungkinkan seorang perempuan mengetahui dan memahami, tetapi juga mengambil sikap terhadap hal-hal yang diketahuinya dan dipahaminya. Dunia-kehidupan perempuan tak hanya ditanggapi sebagai sesuatu yang ada (ontologi) atau sesuatu yang teratur dan bermakna (kosmologi), tetapi juga sebagai sesuatu yang mengandung nilai-nilai dan aturan mengenai nilai-nilai (norma-norma). Di sinilah budaya sebagai sistem makna menjelma menjadi budaya sebagai sistem nilai dan sistem norma.

Secara dikotomis pandangan dunia perempuan dapat digolongkan menjadi (1) pandangan dunia kosmosentris, integratif, holistis-totalistis, statis, siklis, spiritual, dan hierarkis; dan (2) pandangan dunia antroposentris, atomistis, dinamis, linier, material, dan egaliter. Yang pertama perempuan melihat dunia secara luas, utuh, bulat, satu, dan tidak dapat berubah. Selain itu, dunia juga dilihat dapat berulang, berputar, dan tersusun secara berjenjang. Di sini manusia, dalam hal ini perempuan, menganggap dirinya bagian kecil dari dunia dan menghayati dunia secara ruhaniah. Materi tidak terlalu diutamakan dan dihormati. Sementara itu, yang kedua perempuan melihat dunia secara terbatas, terpilah-pilah, terbeda-bedakan, dan dapat berubah-ubah. Selain itu, dunia juga dilihat secara lurus (maju ke depan) dan tersusun secara sistemis, tidak berulang dan tidak berjenjang. Pada kondisi itulah manusia, dalam hal ini perempuan, menganggap dirinya berhadapan dengan dunia dan menghayati dunia sebagai sesuatu yang material. Materi diperlakukan secara positif.
Pandangan dunia perempuan yang pertama berkorelasi atau berhubungan dengan orientasi budaya perempuan yang spiritual, tradisi/tradisional, mitis atau pra-ontologis, dan naif atau semi-transitif, sedangkan pandangan dunia perempuan yang kedua berkorelasi atau berhubungan dengan orientasi budaya perempuan yang material, modern, fungsional, dan transitif. Sebagai contoh, seorang perempuan -katakanlah -- bernama Larasati yang berorientasi budaya spiritual, tradisi, mitis atau pra-ontologis, dan naif cenderung memiliki pandangan dunia yang kosmosentris, integratif, holistis-totalistis, siklis, statis, dan hierarkis; sedangkan seorang perempuan bernama Aruming Kinanti yang berorientasi budaya material, modern, fungsional, dan transitif cenderung memiliki pandangan dunia yang antroposentris, atomistis, dinamis, linier, dan egaliter.

Tokoh-tokoh perempuan yang ada dalam novel Indonesia digambarkan ada yang memiliki pandangan dunia kosmosentris, integratif, spiritual, holistis-totalistis, statis, siklis, dan hierarkis, ada pula yang memiliki pandangan dunia antroposentris, atomistis, material, dinamis, linier, dan egaliter. Sebagai contoh, tokoh perempuan bernama Tini (Sukartini) dalam Belenggu, Popi dalam Kotbah di Atas Bukit, Sri Sumarah dalam Sri Sumarah, Pariyem dalam Pengakuan Pariyem, Srintil dalam Ronggeng Dukuh Paruk, Lintang Kemukus Dini Hari, dan Jantera Bianglala, Bu Bei dalam Canting, Ngaisah dalam Para Priyayi, Ibu Sinder dalam Ibu Sinder, Simbok, Kedasih, dan Sumirat dalam Tirai Menurun, dan Lasi dalam Bekisar Merah merupakan perempuan-perempuan yang berpandangan dunia kosmosentris, integratif, holististotalistis, statis, siklis, dan hierarkis. Meskipun sudah mulai memasuki dunia modern, Tini dalam Belenggu dilukiskan sedemikian pasrah kepada nasibnya, 
sangat taat (malah menghamba) kepada suaminya dokter Sukartono, dan melihat dunia hidup sudah permanen, tidak berubah lagi. Demikian juga Popi dalam Kotbah di Atas Bukit memasrahkan seluruh hidupnya kepada suaminya yang sudah tua renta dan menganggap demikianlah jalan hidup yang harus dilaluinya. Pariyem dalam Pengakuan Pariyem malah digambarkan sangat mengutamakan kehidupan batiniah, menganggap dirinya hanya jagat cilik yang berada dalam jagat gedhe, menyatupadukan alam manusia, alam semesta, dan alam adikodrati, merasa sudah takdir menjadi pembantu rumah tangga dan orang kecil, dan sebagainya. Relatif sama dengan Pariyem, Srintil dalam Ronggeng Dukuh Paruk digambarkan sebagai perempuan yang sangat menerima apa yang menimpa pada dirinya (nrimo ing pandum), menerima nasibnya sebagai ronggeng, menyadari tempatnya di dunia sebagai bagian kecil dunia, sangat mempercayai hal-hal gaib dan mistis, dan sebagainya.

Demikian pula Bu Bei dalam Canting digambarkan sebagai perempuan yang harus seratus persen mengabdi [malah menghamba] pada suami, sangat menekankan kepentingan keutuhan keluarga besar, dan menganggap nasib manusia sudah digariskan oleh Tuhan Yang Mahakuasa meskipun dia sangat piawai berdagang dan memiliki cita-citra modern. Selanjutnya, Ibu Sinder dalam Ibu Sinder digambarkan masih sangat patuh kepada suaminya tanpa reserve, mengutamakan keutuhan rumah tangga daripada memperjuangkan keadilan bagi dirinya, sedemikian pasrah menjalani dan menghayati hidupnya, dan tidak menolak kehidupan feodalistis dalam keluarnya meskipun dia sudah mulai memiliki kesadaran modern. Selanjutnya, Simbok, Kedasih, dan Sumirat dalam Tirai Menurun digambarkan sebagai perempuan yang merasa sebagai bagian alam, menerima nasib masing-masing secara tabah dan senang, kurang mengejar kepentingankepentingan material, dan percaya keutuhan sebagai segala-galanya. Dengan demikian, dapat dikatakan secara negatif bahwa perempuan-perempuan tersebut tidak melepaskan diri dari kekuasaan alam, tidak berusaha mati-matian mengubah hidup mereka masing-masing, tidak memberikan dinamika pada hidup mereka masing-masing, dan tidak menyadari kesederajatan dan keseteraan antarmanusia.

Sementara itu, berbeda dengan tokoh-tokoh perempuanyang dikemukakan di atas, tokoh Tuti dalam Layar Terkembang, Rochayah dalam Belenggu, Sri dalam Pada Sebuah Kapal, Manen (Raumanen) dalam Raumanen, Atik (Larasati) dalam Burung-burung Manyar, Iin Nusamusbida dalam Durga Umayi, Marinetti dan Anggraeni dalam Burung-burung Rantau, Shakuntala, Laila, dan Yasmin dalam Saman, dan Supiyah dalam Aku Supiyah Isteri Hardian merupakan contoh perempuan yang berpandangan dunia antroposentris, atomistis, material, dinamis, linier, dan egaliter dalam arti sepenuhnya. Tuti dalam Sitti Nurbaya merupakan perempuan yang sangat percaya akan kemampuannya sebagai manusia, sangat gigih memperjuangkan perubahan nasib dan kedudukan kaumnya dalam masyarakat, sangat percaya akan pentingnya kemajuan bagi kaum perempuan, dan memperjuangkan kesetaraan lelaki dan perempuan dalam masyarakat. Kemudian Rochayah juga merupakan protipe perempuan yang menemukan individualitasnya, berpikiran visioner, progresif, dan maju pada zamannya, memperjuangkan keseteraan dan keegaliteran gender, dan memandang kehidupan secara dinamis meskipun nasib dan hidupnya tidak membawa keberuntungan. 
Sri dalam Pada Sebuah Kapal digambarkan sebagai perempuan yang sudah menemukan keakuannya dan individualitasnya, melihat kehidupan secara dinamis, memihak dan meyakini pentingnya kesetaraan gender, dan memandang kehidupan secara visioner atau maju ke depan. Sri bisa disebut prototipe perempuan Jawa yang berpandangan dunia antrosentris, dinamis, dan egaliter. Sebagai mahasiswa, Manen dalam Raumanen digambarkan sebagai perempuan yang aktif dalam berbagai kegiatan kemahasiswaan, menyadari individualitasnya, dan berpikiran rasional-logis walaupun nasibnya sangat tragis. Sebagai doktor biologi dan dosen sebuah perguruan tinggi terkemuka, tokoh Atik dalam Burung-burung Manyar benar-benar prototipe perempuan Jawa yang mampu merengkuh pandangan dunia antroposentris dan dinamis. Keyakinan dirinya sangat kuat, kemandirian dan individualitasnya sangat tinggi, berpikiran progresif dan visioner serta kosmopolitan, dan sangat percaya diri akan kemampuan manusia meskipun kelembutannya sebagai perempuan tidak pernah hilang. Iin Nusamusbida dalam Durga Umayi juga merupakan prototipe perempuan Jawa yang sudah masuk secara total dalam pandangan dunia antroposentris, dinamis, linier, dan egaliter. Pergaulannya dengan berbagai kalangan baik pengusaha maupun pejuang cerminan perempuan karier zaman modern. Individualitasnya dan pikiran progresifnya sebagai pejuang dan penguasaha sedemikian maju dibandingkan perempuan sezamannya.

Demikian pula Anggraeni dan Marinetti dalam Burung-burung Rantau digambarkan memiliki individualitas dan kemandirian sangat kuat, pikiran progresif dan kosmoplitan, mobilitas spasial yang mendunia, pergaulan global, dan mampu hidup di dalam berbagai budaya modern di dunia. Selanjut- nya, Shakuntala, Laila, dan Yasmin dalam Saman dapat dikatakan sebagai prototipe perempuan muda Indonesia yang memiliki kemandirian sangat tinggi, pikiran sangat progresif dan mondial, pergaulan global dan kosmopolitan, dan bertindak kritis dan korektif terhadap realitas-realitas yang ditemuinya. Adapun Supiyah dalam Aku Supiyah Isteri Hardian digambarkan sebagai perempuan yang tidak mau pasrah kepada nasibnya, berani mengambil keputusan sendiri untuk permalahan pribadi, berani bertindak atas nama dirinya sendiri sehingga kehidupannya tampak dinamis dan linier. Dapat dikatakan, tokoh-tokoh perempuan tersebut merupakan representasi pandangan dunia modern yang antroposentris, dinamis, linier, dan egaliter.

Di samping kedua pandangan dunia tersebut, dalam novel Indonesia juga ditemukan pandangan dunia perempuan yang peralihan atau transisional. Peralihan atau transisi dari pandangan dunia kosmosentris, integratif, holististotalistis, siklis, statis, dan hierarkis ke arah pandangan dunia antroposentris, atomistis, dinamis, linier, dan egaliter. Tokoh bernama Mariamin dalam Azab dan Sengsara, Sitti Nurbaya dalam Sitti Nurbaya (Kasih Tak Sampai), Rapiah dalam Salah Asuhan, Siti Zaitun dalam $\mathrm{Pa}$ sar, Astiti Rahayu dalam Astiti Rahayu, $\mathrm{Bu}$ Antana dalam Burung-burung Manyar, dan Yuniati dalam Burung-burung Rantau merupakan contoh perempuan yang pandangan dunia mereka berada dalam tahap peralihan atau transisional. Individualitas, kemandirian, dan pikiran progresif mereka sudah tumbuh, tetapi semuanya belum mampu meneratas belenggu struktur dan budaya masyarakat.

Di samping itu, mereka juga sudah mampu mengkritisi, bahkan mengevaluasi struktur dan budaya masyarakatnya, tetapi mereka masih 
mengikuti, bahkan menjalankan struktur dan budaya masyarakat itu. Mereka juga menghendaki perubahan nasib dan dinamika kehidupan, tetapi selalu terbentur struktur sosial dan tata nilai budaya yang berlaku. Sebagai contoh, Sitti Nurbaya sudah merasakan ketidakadilan struktur sosial dan tradisi masyarakatnya, tetapi dia tidak berdaya melepaskan diri dari struktur sosial dan tradisi tersebut. Dia masih menjadi korban struktur sosial dan tradisi masyarakatnya meskipun sudah melakukan perlawanan. Bu Antana juga demikian kritis terhadap budaya kepriyayiannya, tetapi dia tetap mengukuhi berbagai nilai kepriyayian. Walaupun demikian, tokoh-tokoh perempuan tersebut sudah melangkah ke dalam pandangan dunia antroposentris, dinamis, dan rasional meskipun belum masuk secara total ke dalam pandangan dunia antroposentris, dinamis, dan rasional itu. Tampaknya, dalam novel Indonesia, mereka menjadi representasi figur perempuan yang berada dalam masyarakat peralihan Indonesia.

Dalam novel Indonesia yang diteliti, digambarkan atau direpresentasikan bahwa sebagian besar tokoh perempuan berpandangan dunia antroposentris, atomistis, material, dinamis, linier, dan egaliter di samping pandangan dunia peralihan atau transisional. Perempuan dengan pandangan dunia kosmosentris, integratif, holistis-totalistis, statis, siklis, dan hierarkis tidak banyak direpresentasikan dalam novel Indonesia. Dibandingkan dengan perempuan yang berpandangan dunia kosmosentris, statis, siklis, dan hierarkis, perempuan dengan pandangan dunia peralihan juga lebih banyak direpresentasikan dalam novel Indonesia.

Pada umumnya perempuan muda dari golongan menengah, menengahatas, dan ataslah yang berpandangan dunia antroposentris., linier, dinamis, dan egaliter. Sedang perempuan muda dari golongan menengah-bawah dan perempuan tua (setengah baya) dari golongan menengah-atas dan atas memiliki pandangan dunia peralihan atau transisional. Adapun perempuan muda dan tua dari golongan bawah dengan status sosial tidak terpandang memiliki pandangan dunia kosmosentris, integratif, statis, siklis, dan hierarkis. Kenyataan ini mengimplikasikan bahwa novel-novel Indonesia telah menjadi wacana sekaligus arena produksi atau reproduksi dan distribusi pandangan dunia modern. Bahkan modern Barat pada satu sisi dan pada sisi lain menjadi wacana dan arena artikulasi sekaligus resistensi pandangan dunia tradisional yang sudah tidak memadai lagi, harus diubah. Dengan demikian, novel Indonesia telah dijadikan penstabilan dan pengawetan pandangan dunia modern sekaligus diagnosis dan kritik-koreksinegasi pandangan dunia tradisional.

\section{Pandangan Hidup Perempuan}

Pandangan hidup perempuan dapat berupa pandangan hidup yang elitis, aristokratis, feodal, borjuis, konservatif, egaliter, populis, demokratis, moderatakomodatif, inklusif-terbuka, dan/atau progresif-inovatif. Secara teoretis dan praksis, seorang atau segolongan perempuan dimungkinkan mengikuti beberapa pandangan hidup tersebut, tidak selalu hanya satu pandangan hidup. Misalnya, seorang atau segolongan perempuan menengah-atas tradisional (priyayi, misalnya) bisa mengikuti pandangan hidup elitis, aristokratis, feodal, dan konservatif secara serempak. Dapat pula seorang atau segolongan perempuan menengah-atas modern mengikuti pandangan hidup egaliter, populis, demokratis, inklusif, dan terbuka secara serempak.

Tokoh Tuti dalam Layar Terkembang berpandangan hidup egaliter, 
populis, demokratis, inklusif, dan terbuka secara serempak meskipun berasal dari golongan menengah-atas. Demikian pula Marinetti dalam Burung-burung Rantau berpandangan hidup sangat egaliter, populis, demokratis, inklusif, dan terbuka meskipun berasal dari golongan menengah-atas dan secara ekonomis sangat kaya. Sebaliknya, priyayi Bu Bei dalam Canting berpandangan hidup feodal, paternalistis, borjuis, dan sangat konservatif meskipun dalam batas-batas tertentu cukup populis dan demokratis kepada para buruh pembatikannya dan anak-anaknya; demikian pula Bu Cokrosentono dalam Pengakuan Pariyem berpandangan hidup sangat elitis, aristokratis, feodal, parternalistis, dan konservatif karena berasal dari keluarga priyayi luhur, sedang Pariyem dalam Pengakuan Pariyem berpandangan hidup feodal, paternalistis, dan konservatif sekalipun berasal dari kelas bawah. Dari contoh ini juga dapat diketahui bahwa pada umumnya pandangan hidup perempuan yang elitis dan aristokratis cenderung feodal, borjuis, paternalistis, dan/atau konservatif, sedangkan pandangan hidup perempuan yang egaliter dan populis cenderung demokratis-terbuka, akomodatif, dan progresif-inovatif. Meskipun demikian, dapat pula terjadi seorang atau segolongan perempuan yang cenderung berpandangan hidup elitis, aristokratis, feodal, dan paternalistis juga menampakkan kecenderungan pandangan hidup populis dan inklusif. Bu Bei Sestrokusumo dalam Canting digambarkan sebagai perempuan priyayi yang cenderung feodal, paternalistis, dan konservatif, tapi juga cukup populis dan inklusif kepada buruh-buruh pembatikannya karena asal-usulnya memang orang kampung biasa. Demikian juga (Rochayah) Yah dalam Belenggu digambarkan sebagai perempuan menengah-atas yang cenderung elitis dan aristokratis, tetapi juga cenderung cukup egaliter, inklusif, dan demokratis.

Tokoh-tokoh perempuan yang cenderung berpandangan hidup elitis, aristokratis, feodal, paternalistis, dan konservatif di antaranya ialah Ibu Hanafi dalam Salah Asuhan, Nyai Raden Tedja Ningrum (Ibu Suprapta) dalam Pertemuan Jodoh, Siti Mariama dan Puti Renosari dalam Anak dan Kemenakan, Sri Sumarah dalam Sri Sumarah, Ibu dalam Bawuk, Ibu Bei Cokrosentono dalam Pengakuan Pariyem, dan Bu Bei Sestrokusomo dalam Canting. Ibu Hanafi dapat dikatakan berpandangan hidup elitis, aristokratis, paternalistis, dan konservatif karena (antara lain) tidak berani berpendapat -- apalagi berdebat -- dengan suaminya, menghendaki Hanafi kawin dengan Rapiah sebagai balas budi kepada orang tua Rapiah, dan menikmati kehidupan kalangan menengah-atas Minangkabau. Nyai Raden Tedja Ningrum tampak aristokratis, feodal, paternalistis, dan konvervatif ketika tampak melecehkan Ratna -- pacar anaknya -- yang berasal dari kalangan biasa, memaksa Suparta menikah dengan Nyai Raden Siti Halimah, dan mengagungkan kebangsawanannya. Siti Mariama dan Puti Renosari serba mengikut segala kata dan perintah suami mereka (partenalistis), serba mengagungkan kebangsawanan mereka, dan memandang manusia dari kelas lain (kelas bawah) sebagai bukan padanan mereka, dan menghendaki anak mereka kawin dengan calon sepadan (konservatif). Meskipun sudah menikmati pendidikan memadai pada zamannya dan cukup berpandangan cukup maju, Sri Sumarah digambarkan selalu tunduk kepada suami atau laki-laki (paternalis) dan selalu menjaga dan mengikuti tradisi kepriyayiannya sekalipun menuntut ongkos sosial ekonomis sangat besar (aristokratis dan konservatif atau semikonservatif). Kutipan berikut memperlihatkan pandangan hidup Sri Sumarah. 
Buat seorang priyayi Jawa - meskipun priyayi yang sudah jatuh miskin -- contoh apakah yang lebih agung daripada pengorbanan Kunti, ibu para pandawa itu? (Sri tahu betul, bagaimana wayang yang sudah meresap betul dalam tulang sumsumnya. Tiap kali Sri pulang berlibur ke desanya yang sunyi itu, sambil mengelus-elus rambut cucunya -siapa tahu ada kutunya -- embah itu dengan asyiknya bercerita tentang wayang. (SS:12)

Kemudian Bu Bei Cokrosentono merupakan protipe perempuan priyayi Jawa yang sangat elitis, aristokratis, paternalistis, feodalis, dan konservatif karena dia sangat menikmati berbagai keistimewaan priyayi, menjaga dan melaksanakan tradisi kepriyayiannya secara utuh dan tunduk secara total kepada Raden Mas Ngabehi Cokrosentono suaminya. Adapun Bu Bei Sestrokusomo juga merupakan priyayi Jawa yang paternalistis, feodalistis, dan konservatif meskipun cukup populis mengingat asal-usulnya sebagai perempuan kampung sebelum dikawini oleh Raden Mas Ngabehi Sestrokusumo.

Dari contoh-contoh di atas tampak bahwa pada umumnya perempuan tualah yang berpandangan hidup elitis, aristokratis, feodalistis, paternalistis, dan konvervatif yang memang berasal dari kelas menengah-atas dan atas. Walaupun demikian, ada pula perempuan muda dari kelas bawah yang berpandangan hidup feodalistis, paternalistis, dan konservatif, tetapi tidak elitis dan aristokratis, misalnya Pariyem, Srintil, dan Lasi. Jumlah tokoh seperti Pariyem, Srintil, dan Lasi ini hanya sedikit dalam wacana novel serius Indonesia yang diteliti.

Sementara itu, tokoh-tokoh perempuan yang cenderung berpandangan hidup egaliter, populis, demokratis, progresif-inovatif, dan inklusif di antaranya ialah Tuti dalam Layar Terkembang, Sri dalam Pada Sebuah Kapal, Manen dalam Raumanen, (Atik) Larasati dalam Burungburung Manyar, Iin Nusamusbida dalam Durga Umayi, Marinetti dalam Burungburung Rantau, Shakuntala, Laila, dan Yasmin dalam Saman, dan Supiyah dalam Aku Supiyah Isteri Hardian. Sebagai seorang aktivis organisasi Puteri Sedar, pada zamannya dan dalam masyarakatnya, Tuti jelas perempuan yang sangat egaliter, populis, progresif, inklusif, bahkan demokratis. Tuti menolak elitisme, aristokratisme, paternalisme, feodalisme, dan konservatisme yang dipertahankan oleh kaum tua terutama lakilaki. Cara yang ditempuh yaitu dengan menyadarkan atau malah memberdayakan sesama perempuan, membangun kemandirian-individualitas perempuan dalam masyarakat, memperjuangkan ruang publik lebih luas bagi perempuan, dan memperjuangkan kesetaraan perempuan dengan laki-laki.

Sesungguhnya hanya kalau perempuan dikembalikan derajatnya sebagai manusia, barulah keadaan bangsa kita dapat berubah. Jadi, perubahan kedudukan perempuan dalam masyarakat itu bukanlah semata-mata kepentingan perempuan. Kaum lakilaki yang insaf akan kepentingan yang lebih mulia dari kepentingan hatinya yang loba sendiri tentu akan harus mengakui itu.

Tetapi lebih-lebih dari segalanya haruslah kaum perempuan sendiri insaf akan dirinya dan berjuanguntukmendapatpenghargaan dan kedudukan yang lebih layak. Ia tiada boleh menyerahkan nasibnya kepada golongan lain manusia, apalagi golongan laki-laki yang merasa akan keru- 
gian, apabila ia harus melepaskan kekuasaannya yang telah beradab-abad dipertahankannya. Kita harus membanting tulang sendiri untuk mendapat hak kita sebagai manusia. Kita harus merintis jalan untuk lahirnya perempuan yang baru, yang bebas berdiri menghadapi dunia, yang berani membentangkan matanya melihat kepada siapa jua pun. Yang percaya akan tenaga dirinya dan dalam segala soal pandai berdiri sendiri dan berpikir sendiri. Yang berani menanggung jawab atas segala perbuatan dan buah pikirannya. Malahan yang hanya akan melangsungkan sesuatu pekerjaan yang sesuai dengan kata hatinya. Yang berterus terang mengatakan apa yang terasa dan terpikir kepadanya dengan suara yang tegas dan keyakinan yang pasti. (LT:40)

Relatif sama dengan Tuti, sebagai contoh lain, (Atik) Larasati juga protipe perempuan yang sangat egeliter, populis, demokratis, dan inklusif. Larasati bergaul setara dengan perempuan dan laki-laki dalam pelbagai lapangan kehidupan termasuk dengan para pengasuhnya, mempunyai kemampuan berpikir sangat maju, memiliki ruang publik sangat luas, dan juga tidak pernah membanggakan asal-usulnya sebagai priyayi luhur. Lebih-lebih lagi Sri, Iin Nusamusbida, Shakuntala, Laila, dan Yasmin merupakan prototipe perempuan yang sudah sangat kerasan dalam dunia egaliter, demokratis, inklusif, dan populis sebab hal-hal yang masih diperjuangkan oleh Tuti justru sudah mereka menikmati tanpa hambatan dan kendala berarti baik secara struktural maupun kultural. Para perempuan tersebut hampir semuanya berasal dari golongan menengah, menengah-atas, dan/atau atas yang pada umumnya orang muda (dewasa). Hanya sedikit sekali perempuan tua yang berpandangan hidup egaliter, demokratis, inklusif, dan progresif-visioner. Demikian juga sedikit sekali perempuan dari golongan bawah yang berpandangan hidup egaliter, nonpaternalistis, demokratis, dan inklusif.

\section{Gaya Hidup Perempuan}

Secara semantis-denotatif gaya hidup perempuan dapat didefinisikan sebagai "pola tingkah sehari-hari segolongan manusia di masyarakat", dalam hal ini golongan perempuan di dalam masyarakatnya. Secara sosiologis, mengikuti pendapat Kartodirdjo, dkk. (1987), gaya hidup perempuan ini dapat dikatakan sebagai suatu totalitas dari pelbagai tata cara, adat kebiasaan, struktur kelakuan, kompleks lambanglambang, sikap hidup, dan mentalitas dari golongan perempuan yang secara menyeluruh mempengaruhi kehidupan sehari-hari.

Sebagai sebuah totalitas, gaya hidup perempuan memiliki kekhasan yang membedakan atau membuat tidak sama dengan golongan (perempuan) lain. Satu gaya hidup perempuan dengan gaya hidup perempuan lain justru dibedakan oleh adanya keekslusifan (kekhasan). Keeksklusifan yang dimiliki perempuan golongan menengahatas dengan keeksklusifan yang dimiliki perempuan golongan bawah akan membedakan gaya hidup perempuan golongan menengah-atas dengan gaya hidup golongan bawah. Keeksklusifan tersebut dimungkinkan karena dalam batas-batas tertentu gaya hidup perempuan ditentukan dan dijiwai oleh kelas sosial-ekonomis, status sosial-ekonomis, orientasi budaya, pandangan dunia, dan pandangan hidup perempuan yang bersangkutan. Oleh karena itu, gaya hidup perempuan akan menopang keberadaan golongan-golongan perempu- 
an sekaligus melanggengkan orde sosial tempat mereka berada.

Berdasarkan unsur-unsur yang menopang keberadaannya, ada seorang atau sekelompok perempuan mengikuti gaya hidup yang berorientasi pada status askriptif, ritual atau seremonial, religio-magisme, simbolisme dan mitologi irasional, dan/atau solidaritas primordial/mekanis dan komunalitas (etos paguyuban) (Kartodirdjo, dkk., 1987: Kuntowijoyo, 1983). Meskipun demikian, juga bisa terjadi hal sebaliknya, ada seorang atau sekelompok perempuan yang justru menekankan gaya hidup yang berorientasi pada status prestasiprofesional, tidak mengutamakan ritual atau seremonial, mengutamakan antroposentrisme-sekular, tidak menekankan simbolisme yang kompleks dan rumit, lebih menekankan mitologi rasional, dan menekankan solidaritas organis dan sosialitas (etos patembayan). Dua macam gaya hidup perempuan itu sebenarnya bukan suatu polaritas, melainkan suatu kontinum atau suatu rentangan gaya hidup. Hal itu disebabkan pada umumnya manusia tidak mengenal polaritas dalam arti pemisahan secara ketat-tegas (rigid).

Dua macam gaya hidup perempuan tersebut diikuti oleh tokoh-tokoh perempuan yang terdapat dalam novel Indonesia yang diteliti. Terdapat tokoh perempuan mengikuti gaya hidup yang menekankan status askriptif, ritual atau seremonial, simbolisme dan religiomagisme, mitologi irasional, solidaritas mekanis, dan/atau komunalitas. Contohnya, Nyai Raden Tedja Ningrum dalam Anak dan Kemenakan, Siti Mariama dan Puti Renosari dalam Pertemuan Jodoh, (Tini) Sukartini dalam Belenggu, Pariyem dan Bu Bei Cokrosentono dalam Pengakuan Pariyem, Sri Sumarah dalam Sri Sumarah, Bu Bei Sestrokusumo dalam Canting, dan Simbok dalam Tirai Menurun. Ada pula sebagian lain tokoh perempuan mengikuti gaya hidup yang menekankan prestasi-profesional, nonritual atau nonseremonial, nonsimbolis dan rasional, mitologi rasional, solidaritas organis, dan sosialitas. Contohnya, Tuti dalam Layar Terkembang, Corrie de Busse dalam Salah Asuhan, Anni dalam Muda Teruna, Rochayah (Yah) dalam Belenggu, Sri dalam Pada Sebuah Kapal, Larasati dalam Burung-burung Manyar, Iin Nusamusbida dalam Durga Umayi, Siti Zaitun dalam Pasar, Anggraeni dan Marinetti dalam Burung-burung Rantau, dan Shakuntala, Yasmin, dan Laila dalam Saman.

Selain itu, ada pula tokoh perempuan yang gaya hidupnya transisional dari yang menekankan status askriptif, seremonial, mitologi irasional, solidaritas mekanis, dan komunalitas ke arah prestasi-profesional, nonseremonial, mitologi rasional, solidaritas organis, dan sosialitas. Contohnya, Mariamin dalam Azab dan Sengsara, Rapiah dalam Salah Asuhan, Sitti Nurbaya dalam Sitti Nurbaya, Nuraini dan Dirsina dalam Asmara Jaya, Halimah dalam Sengsara Membawa Nikmat, Manen dalam Raumanen, Bawuk dalam Bawuk, Ibu Sinder dalam Ibu Sinder, Bu Antana dalam Burung-burung Manyar, Yuniati dalam Burung-burung Rantau, dan Supiyah dalam Aku Supiyah Isteri Hardian. Hal ini menunjukkan bahwa wacana-wacana novel serius Indonesia merepresentasikan berbagai gaya hidup perempuan.

Berdasarkan analisis data diketahui bahwa sebagian besar tokoh perempuan yang ada dalam novel Indonesia digambarkan memiliki gaya hidup yang menekankan prestasi-profesional, nonritual atau nonseremonial, nonsimbolisme, rasionalitas, mitologi rasional, solidaritas organis, dan sosialitas. Di samping itu juga gaya hidup transisional dari yang menekankan status askriptif dan semonial ke arah prestasiprofesional dan rasional. Hanya sedikit 
perempuan yang digambarkan memiliki gaya hidup yang menekankan status askriptif, ritual atau seremonial, simbolisme, solidaritas mekanis, mitologi irasional, dan komunalitas. Itulah sebabnya, dapat dikatakan bahwa mayoritas wacana novel serius Indonesia merepresentasikan gaya hidup yang menekankan prestasi-profesional, mitologi rasional, solidaritas organis, dan sosialitas; dan juga gaya hidup transisional. Hanya sedikit novel Indonesia yang merepresentasikan gaya hidup yang menekankan status akriptif, mitologi irasional, solidaritas mekanis/primordial, dan komunalitas. Kenyataan tersebut mengimplikasikan bahwa novel Indonesia telah menjadi arena introduksi atau operasi ideologi kelas menengahatas mengingat. Hal itu dikarenakan kelas menengah-atas-lah sebagian besar tokoh perempuan yang memiliki gaya hidup yang menekankan prestasi-profesional, mitologi rasional, dan sosialitas dan gaya hidup transisional.

\section{SIMPULAN}

Salah model dunia-kehidupan yang terdapat dalam novel Indonesia adalah model dunia-kehidupan perempuan. Model dunia-kehidupan perempuan dalam novel Indonesia merupakan gambaran mengenai berbagai bentuk dunia-kehidupan perempuan yang secara nyata/real dihayati, dialami, diikuti, bahkan dijalani oleh perempuan di dalam geografi imajinatif. Model dunia-kehidupan perempuan dalam novel Indonesia tersebut mengandung atau memiliki lima unsur konstitutif (pembentuk), yaitu (1) sosok perempuan, (2) interaksi atau hubungan gender, (3) lingkungan fisikal/spasial/ geografis perempuan, (4) lingkungan sosial budaya perempuan, dan (5) nilai-nilai budaya yang dihayati, dialami, dan/atau diikuti oleh perempuan. Sebagai unsur konstitutif dunia-kehidupan perempuan, ke- lima unsur tersebut secara fenomenologis disebut utuh, bulat, lengkap, padu, dan saling terkait satu sama lain meskipun secara analitis untuk analisis ilmiah dapat dibedakan.

Sosok perempuan yang direpresentasikan oleh novel Indonesia dapat dibagi menjadi tiga macam, yaitu (1) sosok historis, (2) sosok mitologis, dan (3) sosok fiksional. Sosok historis ialah sosok perempuan yang direpresentasikan dalam novel itu ada dalam sejarah, bukan semata-mata ciptaan novel seriusis Sosok mitologis ialah bahwa sosok perempuan yang direpresentasikan dalam novel itu merupakan sosok yang hidup dalam cerita-cerita masyarakat, bahkan diyakini pernah ada meskipun susah sekali dibuktikan keberadaannya. Selanjutnya, sosok fiksional ialah bahwa sosok perempuan yang direpresentasikan dalam novel hanyalah bersifat rekaan sekalipun bisa saja sosok itu meneladani sosok historis.

Tokoh-tokoh perempuan yang direpresentasikan oleh novel Indonesia yang diteliti mengikuti atau menganut berbagai orientasi budaya tersebut. Dalam novel Indonesia, ada perempuan yang direpresentasikan mengikuti orientasi budaya spiritual, tradisi/tradisional, naif, dan mitis. Ada tokoh perempuan yang direpresentasikan mengikuti orientasi budaya transisional (tradisi ke modern), semi-material atau semi-spiritual, ontologis, dan semi-transitif. Ada pula tokoh perempuan yang direpresentasikan mengikuti orientasi budaya material, modern, fungsional, dan transitif. Ketiga orientasi budaya perempuan tersebut dapat ditemukan dalam sebuah novel, dapat pula ditemukan dalam dua novel atau lebih, setidak-tidaknya dua novel berbeda. Hal itu sekaligus menunjukkan bahwa dalam sebuah novel bisa ditemukan satu orientasi budaya perempuan saja, yaitu semata-mata orientasi budaya spiritual, tradisional, dan mitis 
atau semata-mata orientasi budaya material, modern, dan fungsional.

Novel Indonesia melalui tokohtokoh perempuannya telah menjadi instrumen reproduksi orientasi budaya modern, material, fungsional, dan transitif pada satu pihak dan pada pihak lain menjadi instrumen resistensi orientasi budaya spiritual, tradisi, mitis, dan naif. Jadi, novel Indonesia dan tokoh-tokoh perempuan di dalamnya telah menjadi arena pemapanan sekaligus pembongkaran orientasi budaya.

\section{UCAPAN TERIMA KASIH}

Artikel ini diangkat dari penelitian mandiri swadana yang dilaksanakan pada tahun 2008-2009. Ucapan terima kasih disampaikan kepada para mahasiswa yang telah membantu pelakasanan pengumpulan data dan kepada mitra sejawat yang telah membantu kegiatan verifikasi dan triangulasi data dan hasil penelitian.

\section{DAFTAR PUSTAKA}

Geertz, Hildred. 1985. Keluarga Jawa. Jakarta: Grafiti Pers.

Kayam, Umar. 1987. “Keselarasan dan Kebersamaan: Suatu Penjelajahan Awal" dalam Prisma, Maret 1987.
Kayam, Umar. 1989. "Transformasi Budaya Kita". Dalam Horison, Agustus, September, Oktober 1989.

Kartodirdjo, Sartono. 1987. Kebudayaan

Pembangunan dalam Perspektif Sejarah. Yogyakarta: Gadjah Mada University Press.

Kartodirdjo, Sartono, dkk. 1987. Perkembangan Peradaban Priyayi. Yogyakarta: Gadjah Mada University Press.

Kleden, Ignas.1987. Sikap Ilmiah dan Kritik Kebudayaan. Jakarta: LP3ES.

Koentjaraningrat. 1980. Kebudayaan, Mentalitas dan Pembangunan. Jakarta: PT Gramedia Pustaka Utama.

Koentjaraningrat. 1984. Kebudayaan Jawa. Jakarta: PN Balai Pustaka.

Kuntowijoyo. 1989. Masyarakat dan Budaya. Yogyakarta: Tiara Wacana.

Mulder, Niels. 2001. Mistisone Jawa: Ideologi di Indonesia. Jakarta: Gramedia.

Sastrowardoyo, Subagio. 1989. Pengarang Indonesia sebagai Manusia Perbatasan. Jakarta: PN Balai Pustaka. 